\title{
Effect of a Grain Extract on Certain Digestive Physiological Indicators in Early Weaned Rabbits
}

\author{
Melinda Kovács ${ }^{1}$, Emma Kósa ${ }^{2}$, Péter Horn ${ }^{1}$, Zsolt Szendrő ${ }^{1}$, Gábor Milisits ${ }^{1}$ \\ ${ }^{1}$ Kaposvár University, Faculty of Animal Science, Kaposvár, Hungary \\ ${ }^{2}$ Szent István University, Faculty of Veterinary Science, Budapest, Hungary \\ Received January 28, 2008 \\ Accepted March 9, 2009
}

\begin{abstract}
The effect of a non-medicated diet with or without a grain extract feed additive (benzoquinones as main active ingredients) on the growth of rabbits and certain physiological indicators of the digestive tract was examined. One-day-old rabbits of average birth weight were distributed into litters of eight, and these litters were randomly divided into three groups (21-22 litters/group). The control group (Group C) received a basal diet. The diet fed to rabbits of Group IM, was supplemented with a feed additive containing natural basic ingredients (Immunovet-HBM, $1 \mathrm{~kg} / \mathrm{t}$ ); the diet fed to Group M was medicated (tiamulin, oxytetracycline and diclazuril). Three days prior to kindling and up to weaning at 21 days of age of the pups, the does were fed one of the three diets ad libitum. Young rabbits were allowed to consume the same diets beside their mother's milk before weaning.

Significant $(p<0.05)$ difference in body weight between groups was detected only at the ages of 4 and 8 weeks. The $\mathrm{pH}$ of the gastric content remained significantly $(p<0.05)$ higher in Group IM after weaning. Rabbits in Group IM showed the highest pancreatic enzyme (trypsin, lipase, $\alpha$-amylase) activities throughout the period studied. The composition of microflora of the caecum was only slightly altered by the treatment. The total volatile fatty acid content (tVFA) increased with age and from day 28 it was significantly $(p<0.05)$ higher in the $\mathrm{C}$ and IM group than in $\mathrm{M}$ rabbits. The proportion of butyric acid was lower than that of propionic acid even on the $42^{\text {nd }}$ day in Group M.

From the results of this study it is clear that the early weaning of rabbits can be accomplished by the use of a non-medicated diet without any decrease in weight gain. In our study the grain extract feed additive exerted a beneficial effect by increasing the pancreatic enzyme activity and maintaining a better VFA ratio.
\end{abstract}

\section{Digestive physiology, early weaning, grain extract, rabbit}

Mortality in meat rabbit production is primarily due to diseases of the digestive tract (Gidenne and Fortun-Lamothe 2002) and these diseases have a major impact on the welfare of animals. Digestive diseases of rabbits are rarely due to specific pathogenic agents. Acute diarrhoea develops as a result of non-specific enteropathy of multifactorial origin especially in the critical post-weaning period of life. Previous studies (Pascual 2001; Gidenne and Fortun-Lamothe 2002) indicate that changing feed in young rabbits from milk to solid feed markedly affects the maturation and development of the alimentary tract (ecosystem of the caecum, local immune system of the mucous membrane, enzyme activity, etc.) and determines the resistance of rabbits to enteropathogenic agents. These developmental changes during early weaning are not completely understood and necessitate more thorough studies on the developmental process of the digestive tract from birth to 42 days of age. Antibiotics are still widely used to reduce mortality, which has been implicated as a potential concern regarding food safety and human health. In recent years, with increasing concern over drug residues in meat products and increases in bacterial resistance due to the prophylactic use of antibiotics, the use of alternatives has received renewed emphasis. Therefore, the current experiment was conducted to study the effect of a non-medicated diet with or without a grain extract feed additive on the growth of rabbits and certain physiological indicators of the digestive tract.

Address for correspondence:

Melinda Kovács

University of Kaposvár

H-7400 Kaposvár, Guba S.u. 40. Hungary
Phone/Fax: +36 82505970

E-mail: kovacs.melinda@ke.hu

http://www.vfu.cz/acta-vet/actavet.htm 


\section{Materials and Methods}

Experimental animals and design

Three groups of Pannon White does and their progenies were used in the experiment. The does and the kits were housed in flat-deck cages in a closed building, with 16 light hours per day. After weaning, rabbits were reared in fattening cages made of wire mesh until slaughter $\left(2-3\right.$ rabbits per cage), at $15-16^{\circ} \mathrm{C}$ average temperature, a 16 $\mathrm{L}: 8 \mathrm{D}$ lighting cycle and overpressure ventilation.

One-day-old pups of average birth weight were distributed into litters of eight, and these litters were randomly divided into three groups (21-22 litters/group). The litter size was maintained constant until day 21 by replacing dead rabbits with rabbits of similar age and body weight from replacement litters. A total of 512 rabbits were used in the experiment. Feed consumption of the litters and individual body weights (BW) were measured at 3, 4, 8 and 11 weeks.

Eight rabbits per group (altogether 144) were randomly chosen at days 7, 14, 21, 28, 35 and 42 of age. These rabbits were euthanised at 11:00 $\mathrm{h}$ by an overdose of carbon dioxide, bled, weighed, and the weight of the kidneys, liver, heart and lungs was measured. After removing the gastrointestinal tract, the weight and $\mathrm{pH}$ of the gastric, small intestinal and caecal content, as well as the weight and length of the empty stomach, small intestine, caecum and colon were measured. The research protocol, including procedures for the care and treatment of the animals, was reviewed and approved by the Animal Use and Care Administrative Advisory Committee of the Municipal Veterinary Service for Animal Protection (Protocol No. 00618/007/SOM/2003).

Diets

Three days prior to kindling and up to weaning at 21 days of age of the young, the does were fed one of the three diets ad libitum. The control group (Group C) received a basal diet containing $9.7 \mathrm{MJ} \mathrm{DE} / \mathrm{kg}, 16 \%$ crude protein, $4.2 \%$ crude fat and $31.6 \%$ NDF. The diet fed to rabbits of Group IM was supplemented with a feed additive containing natural basic ingredients (Immunovet-HBM, $1 \mathrm{~kg} / \mathrm{t}$ ), while the diet fed to Group M was medicated (50 $\mathrm{mg} / \mathrm{kg}$ tiamulin, $500 \mathrm{mg} / \mathrm{kg}$ oxytetracycline, $1 \mathrm{mg} / \mathrm{kg}$ diclazuril). Young rabbits consumed the same diets beside their mother's milk before weaning, and thereafter during the fattening period. The main active ingredients of the grain extract were benzoquinones (methoxy-p-benzoquinone and 2,6-dimethoxy-p-benzoquinone) produced during the fermentation of wheat germ with yeast, as well as other, hitherto precisely not identified biologically active substances that have antioxidant, immune stimulatory, roborant properties and affect/stimulate the formation of certain growth factors (e.g. IGF-1 and IGF-2) and cytokines (Szende et al. 1998).

Enzyme activity assays

The frozen pancreatic tissue was cleared from fat and homogenized in ice cold saline, in a Potter-Elvehjem homogenizer. The homogenized pancreatic content was diluted with distilled water and centrifuged at $10,000 \times g$ for $10 \mathrm{~min}$; then the supernatants were used for enzyme assays. Protein content of the samples was assayed by the method of Lowry et al. (1961), with bovine albumin used as reference standard. The homogenate was diluted in distilled water, activated by addition of $0.02 \mathrm{M} \mathrm{CaCl}_{2}$ solution, and tested immediately for lipase activity by the method of Schön et al. (1961). To test for the activity of $\alpha$-amylase the Phadebas Amylase Test (Pharmacia Diagnostic AB, Uppsala) was used. The proteolytic zymogens of pancreas were activated by incubation in the presence of enterokinase at $37^{\circ} \mathrm{C}$; trypsin activity was determined by Boehringer colorimetric test (Szabo et al. 1976) and the hydrolytic products were detected with the Folin-Ciocalteu reagent. Enzyme activity data were expressed in katals (kat, $1 \mathrm{~kat}=1 \mathrm{~mol} / \mathrm{s}$ ).

Microbiological examination

For microbiological examinations, a dilution series (with $0.9 \% \mathrm{NaCl}$ ) was made from $1 \mathrm{~g}$ of caecal chyme, the dilutions were smeared onto the surface of the selective culture media. Total aerobe germ count was determined on blood agar after incubation at $37^{\circ} \mathrm{C}$ for $48 \mathrm{~h}$ in an LP-104 type thermostat (LMIM, Esztergom, Hungary). The obligate anaerobe bacteria (incl. Bacteroides) were cultured on Schaedler's agar (Sharlan Chemie, Barcelona, Spain), the selectivity of which was increased by the addition of esculin (Merck, Darmstadt, Germany), neomycin (Merck, Darmstadt, Germany) and Fe-ammonium citrate (Sharlan Chemie, Barcelona, Spain). The gamma sterile Petri dishes (Biolab, Budapest) were placed into Anaerocult culture dishes (Merck, Darmstadt, Germany), in which the anaerobic conditions were ensured with the help of an "Anaerocult A" (Merck, Darmstadt, Germany) gasifying bag. Subsequently the samples were incubated in an LP 104 type thermostat (LMIM, Esztergom, Hungary) at $37^{\circ} \mathrm{C}$ for $96 \mathrm{~h}$. Coliforms were cultured on a Chromocult differentiation medium (Merck, Darmstadt, Germany). The samples were incubated at $37{ }^{\circ} \mathrm{C}$ for $24 \mathrm{~h}$ in a thermostat under aerobic conditions. After the incubation time had elapsed, the colonies were counted with a Titriplaque colony counter (LMIM, Esztergom, Hungary). The colony counts were expressed in $\log 10$ colony forming units (CFU) related to $1 \mathrm{~g}$ of sample.

VFA and $\mathrm{pH}$ measurement

The $\mathrm{pH}$ of the gastric, intestinal and caecal content was measured with a manual automatic $\mathrm{pH}$ meter (OP-110, Radelkis, Hungary). About $3 \mathrm{~g}$ of caecal chyme were homogenized with $4.5 \mathrm{ml}$ metaphosphoric acid (4.16\%), then centrifuged at $10.000 \times g$ for $10 \mathrm{~min}$ and filtrated. The concentration of volatile fatty acids was measured by gas chromatography (Shimadzu GC 2010, Japan). 2-ethyl-butyrate (FLUKA Chemie GmbH, Buchs, Switzerland) was used as internal standard. Parameters: Nukol $30 \mathrm{~m} \times 0.25 \mathrm{~mm} \times 0.25 \mu \mathrm{m}$ capillar column (Supelco, Bellefonte, PA, USA), FID detector, $1: 50$ Split ratio, $1 \mu$ injected volume, helium $0.84 \mathrm{ml} / \mathrm{min}$. Parameters of the detector: air $400 \mathrm{ml} / \mathrm{min}$, hydrogen $47 \mathrm{ml} / \mathrm{min}$, temperature: injector $250{ }^{\circ} \mathrm{C}$, detector $250{ }^{\circ} \mathrm{C}$, column $150{ }^{\circ} \mathrm{C}$ ). 
Statistical analyses

Statistical analysis of the data obtained was carried out by the SPSS statistical software package using the version 10.0. Effect of treatment, age and their interaction was analyzed by the following general linear model, using liveweight as covariate:

$\mathrm{y}_{\mathrm{ijk}, \mathrm{l}}=\mu+\mathrm{T}_{\mathrm{i}}+\mathrm{A}_{\mathrm{j}}+\mathrm{TA}_{\mathrm{ij}}+\mathrm{W}_{\mathrm{k}}+\mathrm{e}_{\mathrm{ij \textrm {jk }}}$,

where $\mu=$ mean, $T_{i}=$ effect of treatment, $A_{j}=$ effect of age, $\mathrm{TA}_{\mathrm{ij}}=$ interaction of treatment and age, $\mathrm{W}_{\mathrm{k}}=$ effect of liveweight, $\mathrm{e}_{\mathrm{ijk} 1}=$ random error.

The significance of between group differences was tested by the Tukey post hoc test.

\section{Results}

Production variables (i.e. body weight, feed consumption and conversion) of the whole stock involved in the experiment were estimated (data not shown). Significant difference between groups was detected only in body weight at ages of 4 and 8 weeks; namely, the body weight of rabbits in Group IM (553 g at week 4 and 1,624 $\mathrm{g}$ at week 8) was significantly $(p<0.05)$ higher than that of rabbits in Group C (529 and 1,589 g, respectively) and $\mathrm{M}$ (503 and 1,548 g, respectively). No significant difference attributable to treatments in feed consumption and feed conversion could be demonstrated. Feed conversion between days 21-42 was 3.16-3.18 g feed/g BW. Mortality between weeks 4 to 11 was $8.9,8.0$ and 5.3\% in Group C, IM and M, respectively.

After birth the relative weight (i.e. \% of BW) of the heart + kidneys + lung was higher (2.6-3.5\%), and decreased with age till day 35 (1.9-2.1\%). In contrast, the relative weight of liver increased with age from $2.8-3.6 \%$ to $4.4-4.8 \%$. The increase in liver weight began on day 14 and lasted till day 35. There was a considerable and significant increase in GI weight between days 21 and 28, i.e. after weaning (Table 1). Significant difference between treatments was found only in the gastrointestinal tract weight/body weight on day 42, which was the highest in $\mathrm{M}$ rabbits.

Table 1. Relative weight $(\% \mathrm{BW})$ of the GI tract $(n=8$, mean \pm SEM)

\begin{tabular}{|c|c|c|c|c|c|c|c|}
\hline \multirow{2}{*}{ Group } & \multicolumn{6}{|c|}{ Age (days) } & Interaction \\
\hline & 7 & 14 & 21 & 28 & 35 & 42 & \multirow{4}{*}{ N.S. } \\
\hline $\mathrm{C}$ & $4.8 \pm 0.1^{\mathrm{a}}$ & $5.4 \pm 0.1^{\mathrm{a}}$ & $7.3 \pm 0.2^{b}$ & $10.1 \pm 0.3^{c}$ & $9.9 \pm 0.3^{c}$ & $9.9 \pm 0.3^{\mathrm{cA}}$ & \\
\hline $\mathrm{IM}$ & $4.5 \pm 0.1^{\mathrm{a}}$ & $5.3 \pm 0.1^{\mathrm{ab}}$ & $6.7 \pm 0.3^{b}$ & $10.1 \pm 0.4^{c}$ & $9.3 \pm 0.5^{\mathrm{c}}$ & $10.1 \pm 0.3^{\mathrm{cA}}$ & \\
\hline M & $4.5 \pm 0.1^{\mathrm{a}}$ & $5.6 \pm 0.1^{\mathrm{ab}}$ & $6.9 \pm 0.2^{b}$ & $10.7 \pm 0.5^{\mathrm{c}}$ & $10.7 \pm 0.8^{c}$ & $12.0 \pm 0.4^{\mathrm{cB}}$ & \\
\hline
\end{tabular}

$\mathrm{C}=$ control, $\mathrm{IM}=$ supplemented with the grain extract, $\mathrm{M}=$ medicated

Significant differences $(P<0.05)$ between ${ }^{\mathrm{a}, \mathrm{b}, \mathrm{c}}$ ages or ${ }^{\mathrm{A}, \mathrm{B}, \mathrm{C}}$ groups, N. S. $=$ non significant

Table 2. Weight and $\mathrm{pH}$ of the gastric content $(\mathrm{n}=8$, mean \pm SEM)

\begin{tabular}{|c|c|c|c|c|c|c|c|}
\hline \multirow{2}{*}{ Group } & \multicolumn{6}{|c|}{ Age (days) } & \multirow[t]{2}{*}{ Interaction } \\
\hline & 7 & 14 & 21 & 28 & 35 & 42 & \\
\hline \multicolumn{8}{|c|}{ Weight $(\mathrm{g})$} \\
\hline $\mathrm{C}$ & $16.8 \pm 2.0^{\mathrm{a}}$ & $20.5 \pm 3.5^{\mathrm{a}}$ & $19.4 \pm 1.6^{\mathrm{a}}$ & $38.2 \pm 3.8^{\mathrm{b}}$ & $59.2 \pm 3.5^{\mathrm{cA}}$ & $62.3 \pm 3.9^{\mathrm{cA}}$ & \multirow{3}{*}{$* * *$} \\
\hline IM & $17.4 \pm 1.5^{\mathrm{a}}$ & $23.1 \pm 2.0^{\mathrm{ab}}$ & $21.6 \pm 1.6^{\mathrm{a}}$ & $37.0 \pm 4.1^{\mathrm{bc}}$ & $48.5 \pm 2.4^{\mathrm{cdAB}}$ & $54.8 \pm 5.3^{\mathrm{dA}}$ & \\
\hline M & $10.8 \pm 1.4^{\mathrm{a}}$ & $18.6 \pm 2.6^{\mathrm{ac}}$ & $21.8 \pm 1.9^{\mathrm{ac}}$ & $25.6 \pm 2.4^{\mathrm{ac}}$ & $41.7 \pm 2.2^{\mathrm{bB}}$ & $28.2 \pm 4.0^{\mathrm{bcB}}$ & \\
\hline \multicolumn{8}{|c|}{$\mathrm{pH}$} \\
\hline $\mathrm{C}$ & $4.8 \pm 0.1^{\mathrm{a}}$ & $5.7 \pm 0.1^{b}$ & $5.3 \pm 0.1^{\mathrm{ab}}$ & $2.5 \pm 0.3^{\mathrm{cA}}$ & $2.1 \pm 0.1^{\mathrm{cd}}$ & $1.7 \pm 0.1^{\mathrm{d}}$ & \multirow{3}{*}{ * } \\
\hline IM & $4.6 \pm 0.2^{a}$ & $5.5 \pm 0.1^{b}$ & $4.8 \pm 0.1^{\mathrm{a}}$ & $2.4 \pm 0.2^{\mathrm{cAB}}$ & $2.0 \pm 0.2^{\mathrm{c}}$ & $2.1 \pm 0.12^{\mathrm{c}}$ & \\
\hline $\mathrm{M}$ & $4.2 \pm 0.2^{\mathrm{a}}$ & $5.6 \pm 0.1^{\mathrm{b}}$ & $5.0 \pm 0.1^{b}$ & $1.7 \pm 0.1^{\mathrm{cB}}$ & $1.9 \pm 0.1^{\mathrm{c}}$ & $1.6 \pm 0.1^{\mathrm{c}}$ & \\
\hline
\end{tabular}

Significant differences $(P<0.05)$ between ${ }^{\mathrm{a}, \mathrm{b}, \mathrm{c}}$ ages or ${ }^{\mathrm{A}, \mathrm{B}, \mathrm{C}}$ groups, $^{*} P<0.05,{ }^{* * * *} P<0.001$

The weight of the gastric content (Table 2) was the lowest in Group M both prior to and after weaning. On day 21 a transient decrease could be observed in the other two groups, 
Table 3. Changes of pancreas tissue hydrolase activity $(n=8$, mean \pm SEM)

\begin{tabular}{|c|c|c|c|c|c|c|c|}
\hline \multirow{2}{*}{ Group } & \multicolumn{6}{|c|}{ Age (days) } & \multirow[t]{2}{*}{ Interaction } \\
\hline & 7 & 14 & 21 & 28 & 35 & 42 & \\
\hline \multicolumn{8}{|c|}{$\alpha$-Amylase (kkat/mg protein) } \\
\hline $\mathrm{C}$ & $53.3 \pm 3.2^{\mathrm{a}}$ & $61.7 \pm 3.2^{\mathrm{a}}$ & $70.0 \pm 3.1^{\mathrm{abA}}$ & $100.0 \pm 5.3^{\mathrm{bcA}}$ & $128.3 \pm 6.4^{\mathrm{cA}}$ & $171.7 \pm 8.5^{\mathrm{dA}}$ & \multirow{3}{*}{$* * *$} \\
\hline IM & $51.7 \pm 1.6^{\mathrm{a}}$ & $65.0 \pm 3.2^{\mathrm{a}}$ & $131.7 \pm 3.3^{\text {bВ }}$ & $173.3 \pm 10.2^{\mathrm{cB}}$ & $213.3 \pm 11.7^{\mathrm{dB}}$ & $246.7 \pm 10.6^{\mathrm{dB}}$ & \\
\hline $\mathrm{M}$ & $66.7 \pm 1.6^{\mathrm{ab}}$ & $60.0 \pm 5.1^{\mathrm{a}}$ & $98.3 \pm 5.3^{\mathrm{bcA}}$ & $126.7 \pm 6.7^{\mathrm{cdA}}$ & $158.3 \pm 8.5^{\mathrm{deA}}$ & $186.7 \pm 10.7^{\mathrm{eA}^{\mathrm{A}}}$ & \\
\hline \multicolumn{8}{|c|}{ Lipase (kat/mg protein) } \\
\hline $\mathrm{C}$ & $710.0 \pm 6.4^{\mathrm{a}}$ & $755.0 \pm 6.1^{\mathrm{abA}}$ & $791.7 \pm 10.7^{\mathrm{bA}}$ & $1023.3 \pm 14.9^{\mathrm{cA}}$ & $1063.3 \pm 15.0^{\mathrm{cA}}$ & $1155.0 \pm 15.3^{\mathrm{dA}}$ & \multirow{3}{*}{$* * *$} \\
\hline IM & $661.7 \pm 5.3^{\mathrm{a}}$ & $853.3 \pm 10.7^{\mathrm{bB}}$ & $956.7 \pm 12.8^{\mathrm{cB}}$ & $1155.0 \pm 13.9^{\mathrm{dB}}$ & $1286.7 \pm 12.8^{\mathrm{eB}}$ & $1346.7 \pm 14.9^{\mathrm{eB}}$ & \\
\hline $\mathrm{M}$ & $686.7 \pm 5.1^{\mathrm{a}}$ & $826.7 \pm 10.8^{\text {bB }}$ & $870.0 \pm 10.2^{\mathrm{bC}}$ & $1006.7 \pm 16.0^{\mathrm{cA}}$ & $1100.0 \pm 13.3^{\mathrm{dA}}$ & $1206.7 \pm 13.2^{\mathrm{eA}}$ & \\
\hline \multicolumn{8}{|c|}{ Trypsin (kat/mg protein) } \\
\hline $\mathrm{C}$ & $590.0 \pm 10.1^{\mathrm{aA}}$ & $603.3 \pm 11.2^{\mathrm{a}}$ & $616.7 \pm 10.6^{\mathrm{abA}}$ & $670.0 \pm 11.2^{\mathrm{bcA}}$ & $700.0 \pm 11.7^{\mathrm{cdA}}$ & $756.7 \pm 10.7^{\mathrm{dA}}$ & \multirow{3}{*}{$* * *$} \\
\hline IM & $553.3 \pm 10.7^{\mathrm{aAB}}$ & $606.7 \pm 10.6^{\mathrm{a}}$ & $726.7 \pm 10.0^{\mathrm{bB}}$ & $788.3 \pm 11.6^{\mathrm{cB}}$ & $840.0 \pm 10.7^{\mathrm{cB}}$ & $953.3 \pm 11.2^{\mathrm{dB}}$ & \\
\hline $\mathrm{M}$ & $525.0 \pm 10.7^{\mathrm{aB}}$ & $585.0 \pm 10.9^{b}$ & $653.3 \pm 10.8^{\mathrm{cA}}$ & $745.0 \pm 11.7^{\mathrm{dB}}$ & $798.3 \pm 12.8^{\mathrm{deB}}$ & $838.3 \pm 11.5^{\mathrm{eC}}$ & \\
\hline
\end{tabular}

Significant differences $(P<0.05)$ between ${ }^{\mathrm{a}, \mathrm{b}, \mathrm{c}}$ ages or ${ }^{\mathrm{A}, \mathrm{B}, \mathrm{C}}$ groups, ${ }^{* * * *} P<0.001$

which was presumably attributable to the lack of appetite associated with weaning.

The $\mathrm{pH}$ value of $<2$, typical of adult rabbits, developed by the first week after weaning (28 days of age) in Group M, whereas in Group $\mathrm{C}$ this decrease was slower. In IM rabbits the $\mathrm{pH}$ remained slightly higher than in the other two groups.

During the experiment there was no significant difference between the groups in the weight of the small intestinal content, with the exception of day 42 , when it was significantly $(p<0.05)$ lower in Group M (data not shown). The $\mathrm{pH}$ of the chyme increased from an initial value of 6.0 up to day 21, after which it stabilized between $\mathrm{pH} 7.8-8.0$ in all three groups.

The activity of pancreatic enzymes (trypsin, lipase, $\alpha$-amylase) increased with age in all groups (Table 3 ). The greatest change was observed in the activity of $\alpha$-amylase. In the control group the increase in $\alpha$-amylase activity could be observed following weaning. In Group IM and $M$ the increase between days 14 and 21 already was significant, IM showing the highest activity throughout the following period. Increases in lipase activity could be observed after 21 days of age. Rabbits in Group IM showed the highest activity throughout the period studied. Differences in trypsin activity amongst the groups only became significant after 21 days.

Table 4. Composition of the caecal microflora expressed in $\log 10$ count/g chyme $(\mathrm{n}=8$, mean $\pm \mathrm{SEM})$

\begin{tabular}{|c|c|c|c|c|c|c|c|}
\hline \multirow{2}{*}{ Group } & \multicolumn{6}{|c|}{ Age (days) } & \multirow[t]{2}{*}{ Interaction } \\
\hline & 7 & 14 & 21 & 28 & 35 & 42 & \\
\hline \multicolumn{8}{|c|}{ Total aerobe germ count } \\
\hline $\mathrm{C}$ & $3.6 \pm 0.3$ & $5.6 \pm 0.4$ & $4.1 \pm 0.5$ & $4.4 \pm 0.3$ & $4.3 \pm 0.5$ & $5.2 \pm 0.3$ & \multirow{3}{*}{$*$} \\
\hline IM & $5.0 \pm 0.5$ & $4.8 \pm 0.4$ & $5.4 \pm 0.5$ & $4.6 \pm 0.4$ & $3.7 \pm 0.3$ & $5.7 \pm 0.3$ & \\
\hline M & $4.6 \pm 0.5^{\mathrm{ab}}$ & $5.6 \pm 0.4^{\mathrm{ac}}$ & $5.2 \pm 0.5^{\mathrm{ab}}$ & $3.1 \pm 0.1^{\mathrm{b}}$ & $3.1 \pm 0.1^{\mathrm{b}}$ & $4.4 \pm 0.6^{\mathrm{bc}}$ & \\
\hline \multicolumn{8}{|c|}{ Strictly anaerobic bacteria } \\
\hline $\mathrm{C}$ & $8.2 \pm 0.2$ & $8.1 \pm 0.1$ & $8.3 \pm 1.4$ & $9.2 \pm 0.2$ & $8.2 \pm 0.5$ & $8.2 \pm 0.2$ & \multirow{3}{*}{ N. S. } \\
\hline IM & $7.8 \pm 0.1$ & $9.4 \pm 0.4$ & $10.0 \pm 0.1$ & $8.9 \pm 0.4$ & $8.6 \pm 0.1$ & $8.7 \pm 0.2$ & \\
\hline $\mathrm{M}$ & $8.3 \pm 0.2$ & $8.4 \pm 0.8$ & $10.1 \pm 0.1$ & $9.9 \pm 0.3$ & $8.5 \pm 0.3$ & $8.2 \pm 0.2$ & \\
\hline \multicolumn{8}{|c|}{ Coliforms } \\
\hline $\mathrm{C}$ & $2.0 \pm 0.3^{\mathrm{aA}}$ & $3.5 \pm 0.5^{b}$ & $3.5 \pm 0.4^{b}$ & $3.1 \pm 0.6^{b}$ & $<2$ & $<2$ & \multirow{3}{*}{ N.S. } \\
\hline IM & $3.6 \pm 0.5^{\mathrm{B}}$ & $3.3 \pm 0.4$ & $5.0 \pm 1.3$ & $2.0 \pm 1.7$ & $<2$ & $<2$ & \\
\hline M & $2.5 \pm 0.4^{\mathrm{aAB}}$ & $4.0 \pm 0.8^{b}$ & $3.1 \pm 0.2^{\mathrm{ab}}$ & $<2$ & $<2$ & $<2$ & \\
\hline
\end{tabular}

Significant differences $(P<0.05)$ between ${ }^{\mathrm{a}, \mathrm{b}, \mathrm{c}}$ ages or ${ }^{\mathrm{A}, \mathrm{B}, \mathrm{C}}$ groups, N. S. $=$ non significant ${ }^{*} P<0.05$ 
Composition of the microflora of the caecum was slightly altered by the treatment (Table 4). The number of the anaerobic bacteria growing on the Schaedler agar remained relatively constant throughout the study. The coliform count remained low in all cases. Significant difference between groups could be established only in one case (in the coliform count on day 7).

There were no inter-group differences in the weight and $\mathrm{pH}$ of the caecal content (data not shown).

The total volatile fatty acid content (tVFA) increased with age and from day 28 it was significantly higher in the $\mathrm{C}$ and IM groups than in $\mathrm{M}$ rabbits (Table 5).

Table 5. Volatile fatty acid content of the caecal chyme $(n=8$, mean \pm SEM)

\begin{tabular}{|c|c|c|c|c|c|c|c|}
\hline \multirow{2}{*}{ Group } & \multicolumn{6}{|c|}{ Age (days) } & \multirow[t]{2}{*}{ Interaction } \\
\hline & 7 & 14 & 21 & 28 & 35 & 42 & \\
\hline \multicolumn{8}{|c|}{$\mathrm{tVFA}(\mathrm{mmol} / \mathrm{kg})$} \\
\hline $\mathrm{C}$ & $17.0 \pm 4.7^{\mathrm{a}}$ & $18.6 \pm 5.7^{\mathrm{a}}$ & $52.1 \pm 7.2^{\mathrm{a}}$ & $93.3 \pm 7.0^{\mathrm{bA}}$ & $85.1 \pm 7.4^{\mathrm{bA}}$ & $104.2 \pm 5.9^{\mathrm{bA}}$ & \multirow{3}{*}{$* * *$} \\
\hline $\mathrm{IM}$ & $8.5 \pm 1.9^{\mathrm{a}}$ & $20.9 \pm 2.5^{\mathrm{a}}$ & $59.9 \pm 11.0^{b}$ & $79.9 \pm 6.2^{\mathrm{bAB}}$ & $75.1 \pm 8.4^{\mathrm{bAB}}$ & $68.0 \pm 7.4^{\mathrm{bB}}$ & \\
\hline $\mathrm{M}$ & $9.3 \pm 2.1^{\text {ac }}$ & $23.0 \pm 3.6^{\mathrm{ab}}$ & $58.9 \pm 7.0^{\mathrm{b}}$ & $52.2 \pm 3.2^{\mathrm{bB}}$ & $47.1 \pm 5.6^{\mathrm{bcB}}$ & $40.2 \pm 5.0^{\mathrm{bcB}}$ & \\
\hline \multicolumn{8}{|c|}{ Acetic acid (mol\%) } \\
\hline $\mathrm{C}$ & $72.7 \pm 4.3$ & $73.0 \pm 4.9^{\mathrm{A}}$ & $73.2 \pm 1.9$ & $74.9 \pm 1.3$ & $78.1 \pm 1.2$ & $76.6 \pm 1.4$ & \multirow{3}{*}{$*$} \\
\hline IM & $75.0 \pm 6.0$ & $76.9 \pm 3.9^{\mathrm{AB}}$ & $72.1 \pm 1.7$ & $78.1 \pm 0.7$ & $77.8 \pm 1.4$ & $76.7 \pm 1.6$ & \\
\hline $\mathrm{M}$ & $86.8 \pm 4.0^{\mathrm{ab}}$ & $87.6 \pm 1.6^{\mathrm{aB}}$ & $75.6 \pm 1.7^{\mathrm{b}}$ & $78.8 \pm 1.6^{\mathrm{ab}}$ & $77.0 \pm 1.3^{\mathrm{ab}}$ & $75.1 \pm 0.7^{\mathrm{b}}$ & \\
\hline \multicolumn{8}{|c|}{ Propionic acid (mol\%) } \\
\hline $\mathrm{C}$ & $14.6 \pm 1.2^{\mathrm{ab}}$ & $17.0 \pm 1.5^{\mathrm{a}}$ & $15.0 \pm 1.3^{\mathrm{ab}}$ & $13.7 \pm 2.3^{\mathrm{ab}}$ & $8.9 \pm 1.0^{b}$ & $8.3 \pm 0.5^{b}$ & \multirow{3}{*}{$* *$} \\
\hline IM & $15.9 \pm 3.9$ & $14.4 \pm 2.2$ & $16.6 \pm 0.8$ & $11.7 \pm 1.0$ & $10.1 \pm 1.0$ & $9.9 \pm 0.9$ & \\
\hline M & $7.9 \pm 1.7$ & $8.8 \pm 1.2$ & $15.0 \pm 1.9$ & $13.5 \pm 1.7$ & $12.8 \pm 1.7$ & $12.7 \pm 1.2$ & \\
\hline \multicolumn{8}{|c|}{ Butyric acid (mol\%) } \\
\hline $\mathrm{C}$ & $4.3 \pm 0.9^{\mathrm{a}}$ & $5.1 \pm 1.2^{\mathrm{a}}$ & $7.3 \pm 0.4^{\mathrm{ab}}$ & $10.1 \pm 1.4^{\mathrm{abc}}$ & $12.2 \pm 1.6^{\mathrm{bc}}$ & $13.2 \pm 0.9^{\mathrm{c}}$ & \multirow{3}{*}{ N.S. } \\
\hline IM & $5.2 \pm 1.8^{\mathrm{a}}$ & $4.7 \pm 0.6^{\mathrm{a}}$ & $5.5 \pm 0.8^{\mathrm{a}}$ & $9.0 \pm 1.0^{\mathrm{ab}}$ & $9.5 \pm 0.6^{\mathrm{ab}}$ & $11.9 \pm 1.2^{b}$ & \\
\hline $\mathrm{M}$ & $2.6 \pm 1.0^{\mathrm{a}}$ & $1.4 \pm 0.4^{\mathrm{a}}$ & $5.2 \pm 0.8^{\mathrm{ab}}$ & $6.6 \pm 0.8^{\mathrm{ab}}$ & $8.8 \pm 0.8^{b}$ & $9.8 \pm 1.3^{b}$ & \\
\hline
\end{tabular}

Significant differences $(P<0.05)$ between ${ }^{\mathrm{a}, \mathrm{b}, \mathrm{c}}$ ages or ${ }^{\mathrm{A}, \mathrm{B}, \mathrm{C}}$ groups, N. S. $=$ non significant, ${ }^{*} P<0.05,{ }^{* *} P<0.01$, ${ }^{* * * *} P<0.001$

The proportion of acetic acid within the tVFA was around $70-80 \%$, and there were no major inter-group differences. The proportion of propionic and butyric acids within the tVFA, and the $\mathrm{C} 3 / \mathrm{C} 4$ value indicating the ratio of the two volatile fatty acids as related to each other were different in the groups studied. In suckling rabbits the $\mathrm{C} 3 / \mathrm{C} 4$ ratio is $>1$. In groups $\mathrm{C}$ and IM after consumption of solid feed the percentage proportion (mol \%) of propionic acid decreased while that of butyric acid increased, resulting in continuously decreasing $\mathrm{C} 3 / \mathrm{C} 4$ values. In Group $\mathrm{M}$ the proportion of butyric acid was lower than that of propionic acid even on the $42^{\text {nd }}$ day.

\section{Discussion}

The digestive tract is able to adapt to the qualitative and quantitative nutritional changes around weaning. Growth of the body is rapid around weaning (i.e. between the ages of 7 and 35 days). The weight of the GI organs was found to concur with most of the relevant data in the literature (Lebas and Laplace 1972; Alus and Edwards 1977; Piattoni et al. 1997). The weight of the GI followed an almost linear curve between the ages of 7 and 28 days. It seems that early weaning and the subsequent higher consumption of solid feed between days 21 and 28 affected the weight of the digestive system. 
According to Dojana et al. (1998) changes of enzyme activity are genetically determined; however, the time of weaning, the amount and composition of solid feed consumed can also influence enzyme activity. They found the highest lipase activity on d 15 with slight decline afterwards. Marounek et al. (1995) also observed the lipase activity to decrease with age. Similarly to the data presented in the current study, others also reported detection of the amylase activity in the pancreas before solid feed consumption. Corring et al. (1972) and Lebas et al. (1977) identified amylase in the pancreas at 1 and 7 days of age. Higher consumption of solid feed after weaning has been shown to stimulate amylase production in the pancreas. Scapilleno et al. (1999) reported a nearly 4\% increase after weaning. Although the effect of changes in enzyme activities on the digestibility of different nutrients was not examined, the current study shows an earlier increase and a higher enzyme activity in the rabbits supplemented with grain extract.

It is generally accepted that the antimicrobial effect of feed additives is mainly due to the altered microflora and microbial activity in the GI tract. In rabbits, the highest microbial activity is in the caecum. Microbial fermentation of plant carbohydrates results in volatile fatty acid (VFA) production which is absorbed and covers about $40 \%$ of the maintenance requirement (Marty and Vernay 1984). In this study, feeding antibiotic containing diet resulted in lower VFA production compared to the other two groups (i.e. C and IM). It could be presumably due to the slightly lower germ count or lower microbial activity as the main effect of the in-feed antibiotic. Enumeration of the bacteria may, however, not reflect their metabolic activity (Gidenne 1996). Higher VFA production could be beneficial in respect of better energy supply and better body weight gain as a consequence. Higher VFA content is favourable also because they provide the main metabolic fuel for the mucosa of the large intestine (Roediger 1986). The other difference between groups fed antibiotic containing (M) or antibiotic free (C and IM) diet was in the proportion of propionic and butyric acids within the tVFA, and the $\mathrm{C} 3 / \mathrm{C} 4$ value. In Group $\mathrm{M}$ the proportion of butyric acid was lower than that of propionic acid even after weaning. So, in the other two groups fermentation resulted in higher butyric acid production. Butyrate has been shown to be the preferred substrate for normal coloncyte growth and promotes normal cell phenotype by stabilizing DNA and repair of damage (Leavitt et al. 1978). It has been shown that antibiotics reduce the rate of fermentation, reduce the amino acid catabolism and increase the efficiency of microbial protein production in relation to the amount of glucose fermented (Vis ek 1978). In our case the reduction in the fermentation was shown (by the lower VFA content of the caecal chyme); however, the positive effect, i.e. improvement in utilisation of protein and energy and a better production as a consequence could not be detected in rabbits fed the medicated diet.

Whether the higher propionate and lower butyrate activity in Group M may be explained by the different substrate supply in the large intestine due to different enzyme activities in the small intestine is not consistent. Different VFA production was not related to the altered pancreatic enzyme activity, rather with the altered activity of microbial enzymes due to different supplementation (grain extract vs. antibiotics).

From the results of this study it is clear that early weaning of rabbits may be accomplished using a non-medicated diet without any decrease in weight gain.

The benzoquinones have been examined mainly as immune-modulators, antimetastatic, apoptosis-enhancing and antioxidant chemical substances (Szende et al. 1998). In agreement with human studies the benzoquinones containing fermented wheat extract had a protective effect against Mycoplasma gallisepticum infection of chickens (Stipkovits et al. 2004). So, its application in animal production can be favourable especially in the case of suboptimal management conditions. In our case the grain extract feed additive exerted a beneficial effect presumably by increasing the pancreatic enzyme activity and maintaining a better VFA ratio, but further studies are needed to define the mode of action. 


\section{Vliv obilného extraktu na vybrané fyziologické ukazatele trávení u časně odstavených králíků}

V této studii byl zkoumán vliv nemedikované diety s nebo bez př́idavku extraktu z obilných zrn (benzochinony jako hlavní aktivní ingredience) na růst králíků a vybrané fyziologické ukazatele trávicího traktu. Jednodenní králíci o průměrné porodní hmotnosti byli rozděleni do osmi vrhů, které byly poté náhodně rozděleny do tří skupin (21 - 22 mlád’at/ skupina). Kontrolní skupině (C) byla podávána základní dieta. Krmivo podávané králíkům ze skupiny IM, byla doplněno o aditivní krmný přídavek obsahující př́rodní ingredience (Immunovet HBM, $1 \mathrm{~kg} / \mathrm{t}$ ); skupina $\mathrm{M}$ byla krmena medikovaným krmivem s obsahem tiamulinu, oxytetracyklinu a diklazurilu. Tři dny před porodem až do odstavu mládat ve 21 dnech stárí, byly ramlice krmeny jednou ze tří diet ad libitum. Před odstavem bylo mlád'atům králíků kromě mateřského mléka umožněno konzumovat stejnou dietu s matkou.

U mlád'at z jednotlivých skupin byl signifikantní rozdíl v tělesné hmotnosti pozorován pouze ve věku 4 a 8 týdnů. Hodnota $\mathrm{pH}$ žaludečního obsahu byla signifikantně zvýšená po odstavu mlád'at ze skupiny IM. Králíci ze skupiny IM vykazovali také nejvyšší aktivity pankreatických enzymů (trypsin, lipáza, $\alpha$-amyláza) po celou dobu studie. Složení mikroflóry slepého střeva se u králíčat $\mathrm{z}$ různých skupin odlišovalo pouze zanedbatelně vlivem podávání obohaceného krmiva. Celkový obsah celkových mastných kyselin (tVFA) stoupal s věkem a od 28. dne stáŕí byl významně vyšší u jedinců ze skupiny $\mathrm{C}$ a IM než u králíků ze skupiny M. Podíl kyseliny máselné byl oproti kyselině propionové nižší u králíků ze skupiny $\mathrm{M}$ dokonce už 42. den.

\section{Acknowledgement}

The research was funded by the Hungarian Academy of Sciences (2006 TKI 117), and the OTKA foundation (project no.: T046999).

\section{References}

Alus G, Edwards NA 1977: Development of the digestive tract of the rabbit from birth to weaning. Proc Nutr Soc 36: 3 A

Corring T, Lebas F, Courtot D 1972: Controle de l'équipement enzymatique du pancréas exocrine du lapin de la naissance a 6 semaines. Annls Biol Anim Biochim Biophys 12: 221-231

Dojana, N, Costache M, Dinischiotu A 1998: The activity of some digestive enzymes in domestic rabbits before and after weaning. Anim Sci 66: 501-507

Gidenne T 1996: Nutritional and ontogenic factors effecting rabbit caeco-colic digestive physiology. Proc 6th World Rabbit Congress, Toulouse, Vol. 1, pp. 13-28

Gidenne T, Fortun-Lamothe L 2002: Feeding strategy for young rabbits around weaning: a review of digestive capacity and nutritional needs. Anim Sci 75: 169-184

Leavitt J, Barrett JC, Crawford BD, Tso POP 1978: Butyric acid suppression on the in vitro neoplastic state of Syrian hamster cells. Nature 271: 262

Lebas F, Corring T, Courtot D 1977: Equipment enzymatique de pancreas exocrine chez le lapin, mise en place et evolution de la naissance au sevrage. Relation avec la composition du regime alimentaire. Ann Biol Anim Biochem Biophys 11: 399-413

Lebas F, Laplace JP 1972: Mensuration viscérale chez le lapin. 1, Croissance du foie, des reins et des divers segments intestinaux entre 3 et 11 semaines d'age. Annls Zootech 21: 37-47

Lowry OH, Rosebrough NJ, Farr AL, Randall RJ 1961: Protein measurement with the Folin phenol reagent. J Biol Chem 193: 265-275

Marounek M, Vovk SJ, Skrivanova V 1995: Distribution of activity of hydrolytic enzymes in the digestive tract of rabbits. Brit J Nutr 73: 463-469

Marty J, Vernay M 1984: Adsorption and metabolism of the volatile fatty acids in the hindgut of the rabbit. Brit J Nutr 51: 265-277

Pascual JJ 2001: Recent advances on early weaning and nutrition around weaning. Proc 2nd COST Meeting, Gödöllő, Hungary, pp. 31-36

Piattoni F, Maertens L, Mazzoni D 1997: Effect of weaning age and solid feed distribution before weaning on performances and caecal traits of young rabbits. Proc $2^{\text {nd }}$ International Conference on Rabbit Production in Hot Climates (Adana 7-9 September, 1998). Cahiers Options Méditerranéennes, pp. 85-92

Roediger WEW 1986: Interrelationship between bacteria and mucosa of the gastrointestinal tract. In: Hill, MJ (Ed.).: Bacterial metabolism in the digestive tract. CRC Press, Boca Raton, pp. 202-209 
Scapilleno C, Gidenne T, Fortun-Lamothe L 1999: Digestive capacity of the rabbit during the post-weaning period, according to the milk/solid feed intake pattern before weaning. Reprod Nutr Dev 39: 423-432

Schon H, Rassler B, Henning N 1961: Über die Untersuchung der exkretorischen Pankreasfunktion. Methoden zur Aktivitätsbestimmung von Trypsin, Chymotrypsin, Carboxypeptidase, Lipase und Diastase. Klin Wschr 39: $217-222$

Stipkovics L, Lapis K, Hidvégi M, Kósa E, Glávits R, Resetár A 2004: Testing the efficacy of fermented wheat germ extract against Mycoplasma gallisepticum infection of chickens. Poultry Sci 83: 1844-1848

Szabo J, Ribiczeine Szabo P, Rafai P 1976: Study of the activity of some pancreas originated hydrolases in pigs kept in different environmental temperature [in Hungarian]. Hung Vet J 31: 325-328

Szende B, Raso E, Hidvegi M, Tomoskozine FR, Paku S, Pronai L, Bocsi J, Lapis K 1998: A new benzoquinonecontaining antimetastatic product [in Hungarian]. Hung Med J 48: 2893-2897

Visek WJ 1978: Mode of growth promotion by antibiotics. J Anim Sci 5: 1447-1469 